\title{
STAIR CLIMBING AND ABILITY TO WORK FOR PARAPLEGICS WITH COMPLETE LESIONS-A SIXTEEN-YEAR FOLLOW-UP
}

\author{
By R. McAdaM, C.S.P. and H. Natvig, M.D. \\ State Rehabilitation Institute, Oslo, Norway
}

Key words: Stair climbing; Working ability; Complete paraplegics.

\section{Introduction}

THE State Rehabilitation Institute in Oslo admits patients for medical and vocational rehabilitation mainly from the south-eastern part of Norway. Patients with a diversity of socio-medical ailments are admitted, providing that there exists a reasonable possibility for future employment.

During the last 30 years we have been specially interested in the vocational rehabilitation of paraplegics with complete and incomplete lesions (Bramness \& Natvig, I975; Kaasa \& McAdam, I967; McAdam, I974; Natvig \& McAdam, I978). Approximately IO-I 5 new cases have been admitted to our unit annually. This would comprise some 30-50 per cent of all traumatic paraplegics in Norway according to the national estimate (Gjone \& Nordlie, 1978).

The paraplegics are transferred to us weeks or months after the accident; however, we prefer to initiate our training once the spinal fractures are consolidated. The physical training programme (McAdam, 1974; Natvig \& McAdam, 1978) is strenuous and has been compared to the gruelling demands made on able-bodied athletes. We attempt to give our patients a physical and psychological boost in the hope that they will be able to cope adequately with every-day demands which they will encounter as paraplegics in the years ahead. In a IO-year follow-up study of 42 paraplegics with complete lesions (Natvig \& McAdam, I978) we found that 74 per cent were able to climb and descend 20 standard stairs after a physical training period of approximately IO-I 5 weeks' duration.

It has been contended that these patients would resolve to wheel-chair use and dependence soon after they were discharged from the Institute and that the intense physical training programme was therefore a waste of time.

\section{Material and Methods}

In order to elucidate whether our patients continued to use their orthoses and crutches after discharge we undertook a I6-year follow-up of all our paraplegics with complete lesions ( $\left.\mathrm{T}_{\mathrm{I}}-\mathrm{L}_{3}\right)$. All patients living at the time of the follow-up received a questionnaire and the reply frequency was remarkably good. Only a few patients failed to return the questionnaire and it was possible in these cases to obtain the necessary data by means of telephone contact. However, we have not performed a systematic check on all of the answers. It turned out that we had personal knowledge of nearly all of our patients, either due to ordinary medical follow-ups, or through organised sports for the disabled. Consequently, we were in a position to check the validity of most of the answers. 
All in all, there were 69 patients with complete paraplegia ( $\left.\mathrm{T}_{\mathrm{I}}-\mathrm{L}_{3}\right)$ in the $\mathrm{I}_{6}$ year period 1960-75. Eight persons were dead at the time of follow-up in the autumn of 1978. If they had lived they would have attained an average age of 60.4 years (range 46-90 years). Thus the case material for analysis consists of $6 \mathrm{I}$ patients.

\section{Results}

Table I shows the age at the follow-up (autumn 1978) and the level of the lesions. There were six females and 55 males. The average duration from the date of injury until the follow-up was I I.6 years (range 3-3 I years) with Standard Deviation 6.0. Minimum follow-up time after discharge was 3 years. Some patients were admitted to the Institute years after the injury, e.g. one person who was injured in 1947 was admitted in 1964 and followed up in 1978 (3I years). At the follow-up 32 persons said that they used orthoses and crutches daily. Ten used them occasionally, and 19 not at all. Specifically, this means that 42 (69 per cent) used walking appliances regularly. Twenty used the appliances more than one hour daily, and 22 from half-hour to one hour daily.

Table II shows the results regarding the patients' ability to walk Ioo metres indoors, 500 metres out of doors (Fig. I) and up and down 20 standard stairs (Fig. 2), and whether at the time of follow-up the patients were vocationally employed or not. The following kinds of employment were registered:

I5 office work

8 factory work

8 studying at schools or universities

3 own business (watchmakers)

I teacher

I social worker

TABLE I

The level of the lesions (complete paraplegia) and age at the follow-up in the autumn of 1978

\begin{tabular}{lcccc}
\hline & \multicolumn{3}{c}{ Level of the lesion } & Total \\
\cline { 2 - 4 } Age & TI-T5 & T6-TIO & TII-L3 & \\
\hline 20-29 years & 7 & I3 & 0 & I9 \\
30-39 years & 7 & 3 & I2 & 26 \\
40 years and more & I & 32 & I6 \\
Total & I4 & 23 & 24 & 61 \\
\hline
\end{tabular}

TABLE II

Results of follow-up of 6I patients in the autumn of 1978

Able to walk roo metres indoors

Able to walk 500 metres out of doors

Able to climb up and down 20 stairs

Working for a living

$$
\begin{aligned}
& 39=64 \% \\
& 22=36 \% \\
& 36=59 \% \\
& 36=59 \%
\end{aligned}
$$




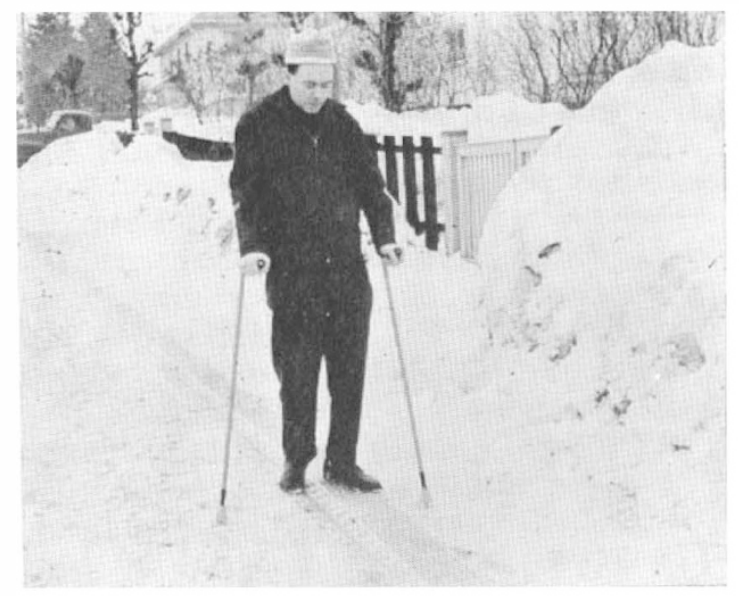

FIG. I

Complete paraplegic walking on snow with orthoses and crutches.

FIG. 2

Complete TH6 paraplegic managing spiral stairs without handrails.

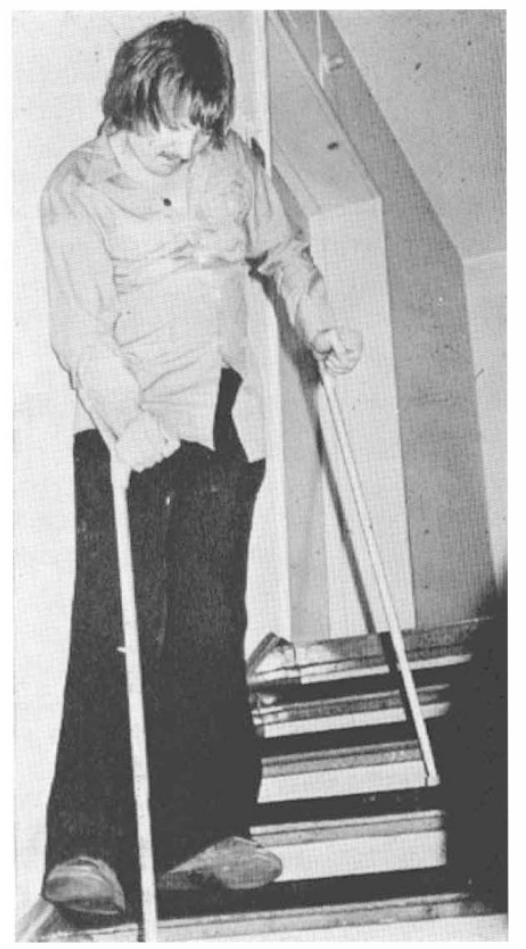

In addition, six patients had part-time work with a reduced invalid pension.

Table III shows the level of intelligence expressed as IQ. Compared to a 'normal' population the intelligence level was somewhat higher.

In order to evaluate the importance of some factors investigated in relation to the success of rehabilitation, chi-square tests on tables with one degree of freedom have been done. Table IV shows an example of this calculation. Chi-square was in this case $\mathrm{I} \cdot 43$ which is not statistically significant for this particular relationship $(\mathrm{P}<0.30)$.

Table $\mathrm{V}$ shows different chi-square values and significance levels for other relationships. There is a statistical significance between: $(a)$ the ability to climb 20 stairs and the ability to work $(P<0.05)$; and $(b)$ intelligence and ability to work $(\mathrm{P}<0.0 \mathrm{I})$.

\section{TABLE III}

Intelligence level expressed in terms of IQ

\begin{tabular}{lr} 
IQ less than 70 & I \\
IQ 7I-85 & I \\
IQ 86-I00 & 9 \\
IQ IOI-II4 & 29 \\
IQ II5 and more & 2 I \\
Total & 6 I \\
\hline
\end{tabular}




\section{TABLE IV}

Relationship between level of the lesion (above or below T8) and ability to climb 20 stairs up and down

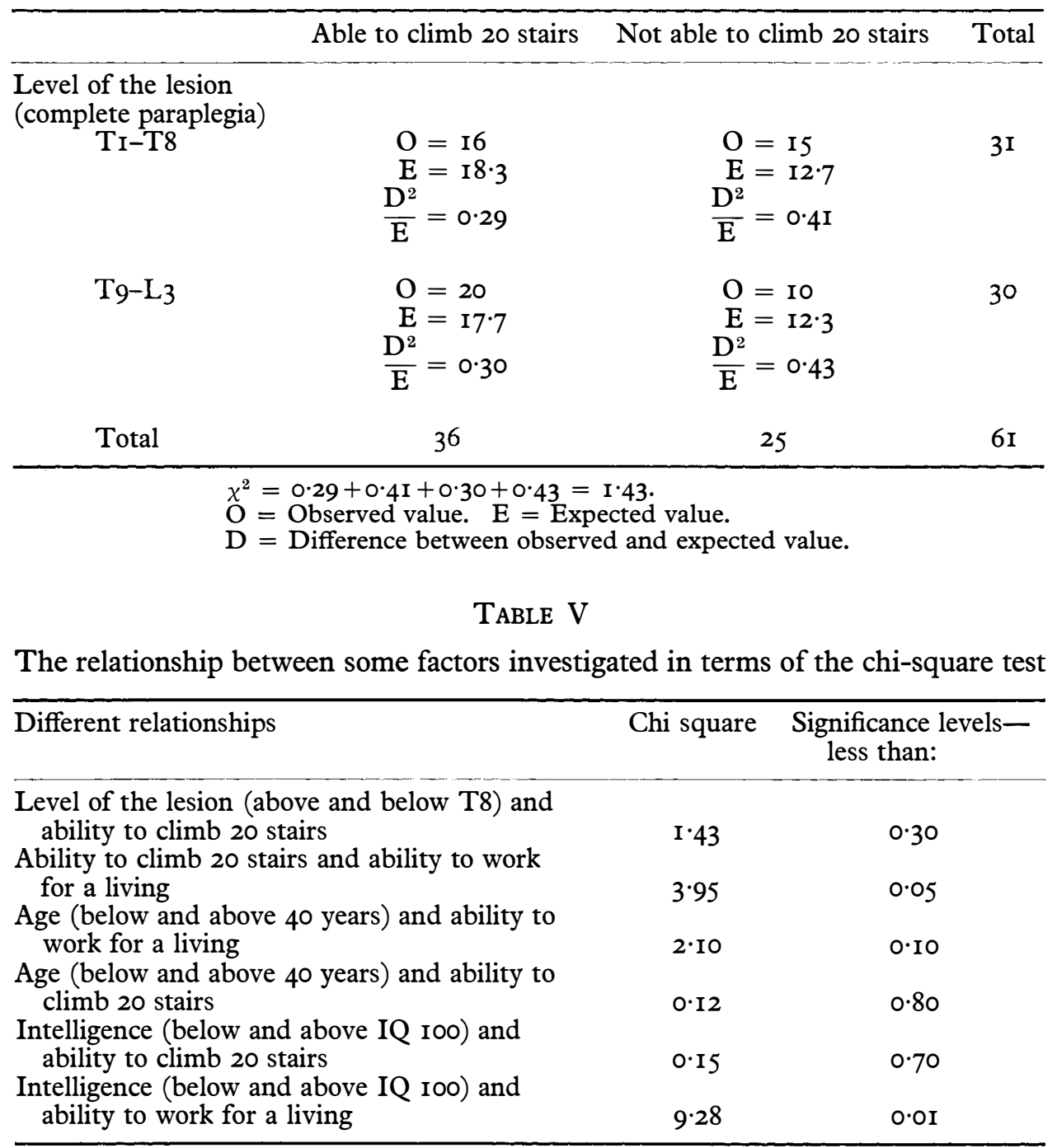

\section{Discussion}

There are many factors influencing the outcome of vocational rehabilitation. The medical problems are of special significance regarding the rehabilitation of paraplegics with complete lesions. In the acute phase it is necessary to cope with complications like pressure sores, urinary calculi, infections, disuse osteoporosis, myositis ossificans and depression.

In the next phase our attention may be directed towards secondary complications such as troublesome spasms, compensation neurosis and an exaggerated or 
unrealistic desire on the patient's part to become the 'proud' possessor of an electric wheelchair or a large though unsuitable American motor-car. The patient may also have an alcohol problem which has to be dealt with. Furthermore, during this phase one may have to consider the detrimental effects of inadequate education, a difficult social background with minimal family support, and perhaps a poor local subsistence offering severely limited employment alternatives. These factors have therefore a direct bearing on the action which has to be taken. We have found it expedient to commence the rehabilitation procedure with emphasis on the physical aspect where we attempt to get the patient to become independent of his wheelchair as soon as possible. To reach this goal it is imperative that complications must be combated successfully.

On completion of the programme the patient will have reached a stage of mental and physical proficiency of such a magnitude that he will have developed the necessary resources and reserves in order to continue with his vocational rehabilitation. In a series of 57 patients with complete and incomplete lesions Kaasa and McAdam (1967) reported that 84 per cent started work after discharge from the Institute.

In this I6-year follow-up of complete paraplegics, 59 per cent of those still living, or 52 per cent of the whole material were still working for a living. There was a statistical significance between intelligence and ability to work and ability to climb 20 stairs and work.

It is difficult to compare the results of vocational rehabilitation of paraplegics. Table VI is an attempt based on publications. One must bear in mind, however, that the figures are not strictly comparable because the patient material at the various clinics differ in relation to age, sex, level and type of lesion. Obviously a spinal unit treating mainly complete tetraplegics will not be able to demonstrate the same success with work resettlement as a unit with a predominance of incomplete paraplegics. The table does indicate, however, that our treatment method judging by the rate of employment at follow-up is not inferior to other results reported in Table VI.

\section{TABLE VI}

Results of vocational rehabilitation of paraplegics in different parts of the world

\begin{tabular}{|c|c|c|c|c|c|}
\hline Country & Author (year) & $\begin{array}{c}\text { Material } \\
(\mathrm{C}=\text { complete } \\
\mathrm{I}=\text { incomplete })\end{array}$ & $\begin{array}{l}\text { No. of } \\
\text { patients }\end{array}$ & $\begin{array}{l}\text { Follow-up } \\
\text { time in } \\
\text { years }\end{array}$ & $\begin{array}{l}\text { Per cent } \\
\text { full time } \\
\text { work }\end{array}$ \\
\hline Australia & Cheshire (I968) & Paraplegia (C \& I) & 325 & Seven & $33 \%$ \\
\hline England & Guttmann (I973) & $\begin{array}{l}\text { Tetra- and paraplegia } \\
\text { (C \& I) } \\
\text { Polio and others }\end{array}$ & 2012 & Eleven & $54.5 \%$ \\
\hline France & Maury (I964) & Male paraplegics & 250 & $\begin{array}{l}\text { At least } 2 \\
\text { years }\end{array}$ & $16 \%$ \\
\hline Germany & Meinicke (I964) & Paraplegic miners & 247 & Unknown & $7 \%$ \\
\hline Norway & McAdam/Natvig (I979) & Paraplegics (C) & 61 & Sixteen & $59 \%$ \\
\hline Scotland & Johnson (I972) & $\begin{array}{l}\text { Tetra- and paraplegics } \\
\text { (C \& I) }\end{array}$ & 50 & $\begin{array}{l}\text { At least I } \\
\text { year }\end{array}$ & $26 \%$ \\
\hline Spain & Forner (1976) & $\begin{array}{l}\text { Tetra- and paraplegia } \\
\quad(\mathrm{C} \& \mathrm{I})\end{array}$ & 200 & Unknown & $12 \%$ \\
\hline
\end{tabular}




\section{Conclusion}

We would like to conclude that our endeavours to get the paraplegics to ambulate with orthoses and crutches is a significant indication towards the accomplishment of successful vocational rehabilitation.

Once taught the correct crutch walking technique which economises on energy output, most of our patients will continue to use their walking appliances years afterwards.

We believe that it is important to maintain regular contact with our former patients in order to help them with medical and other problems. We maintain that this follow-up should be undertaken by specialists-and not family doctors-who are acquainted with all the different facets of this particular problem. So far, we have not encountered ill effects of our treatment programme. It may be worth noting that we have not observed shoulder pain in our walking patients. This problem has recently been reported by Nichols et al. (1979) amongst wheelchair users.

To sum up, we are convinced that our physical training programme for our complete paraplegics is not a waste of time. Most of our patients continue to use their crutches and orthoses for years after they have been trained to do so. We believe that a paraplegic who is able to ambulate well on crutches, and in particular, if he can climb stairs, is endowed with the following advantages compared to his fellow sufferer who is confined to a wheelchair:

I. Less disuse osteoporosis.

2. Less decubitus ulcers.

3. Less urinary calculi and infections.

4. Less shoulder pain.

5. Greater chance of successful vocational rehabilitation.

6. Better chances of keeping a job.

7. A wider range of activities of daily living at home, at work, and on vacation.

8. Less dependence on help from others.

9. A sense of accomplishment and self-respect after completion of a job well done.

\section{SUMMARY}

A I6-year follow-up study of 69 paraplegics with complete lesions from $\mathrm{TI}_{\mathrm{I}}-\mathrm{L}_{3}$ is presented. The intention was to reveal to what extent crutch walking proficiency was retained years after discharge and what benefits were derived by adept crutch walkers compared to wheelchair-bound patients.

At follow-up 69 per cent claimed to use their appliances regularly. Fifty-nine per cent of those still alive were still working for a living. There was a statistical significance between intelligence and ability to work and ability to climb 20 standard stairs and to work.

The authors mention several advantages which the well-trained crutch walker is endowed with compared to the wheelchair bound patient who has not been given adequate opportunity to attain optimal crutch ambulation proficiency.

\section{RÉSUMÉ}

Sur une période de 16 ans, on a étudié 69 paraplégiques présentant une lésion complète de $D_{1}$ à $L_{3}$. L'intention était de mettre en évidence de quelle façon, la capacité de marcher 
avec des cannes était utilisée après le départ du milieu hospitalier, et quel en était les bénéfices retirés par ceux qui marchaient avec des cannes par rapport aux utilisatéurs du fauteuil.

Cette étude démontre que le $69 \%$ utilise régulièrement leurs cannes. $59 \%$ de ceux qui étaient encore en vie avait une activité lucrative. La statistique démontre la relation entre l'intelligence et la faculté à monter 20 marches d'escalier et à travailler.

Les auteurs mentionnent de nombreux avantages avec les paraplégiques bien entraînés à marcher avec des cannes en comparaison à ceux qui restent dans leur fauteuil roulant et qui n'ont pas eu l'occasion d'être rééduquer de manière à marcher avec des cannes.

\section{ZUSAMMENFASSUNG}

Die Verfasser präsentieren eine I6-jährige Studie von 69 Paraplegikern mit kompletten Schäden TI-L3. Der Zweck war eine Klärung zu welchem Grade in den Jahren nach der Entlassung die Geschicklichkeit in Krückengang bewahrt war, und welche Vorteile die die gut trainierte Krückengänger in Vergleich mit rollstuhlgebundenen Patienten hatten.

Bei der Kontrolle gaben $69 \%$ vor, dass sie ihre Krücken und Bandagen regelmässig benutzten. $59 \%$ noch am Leben waren in stetiger Arbeit. Statistische Signifikanz zwischen Intelligenz und Arbeitsfähigkeit und zwischen Fähigkeit 20 Standard Stufen zu gehen und Arbeitsfähigkeit wurde gefunden.

Die Verfasser erwähnen viele Gewinne, die die gut trainierte Krückengänger erreicht haben in Vergleich mit rollstuhl-gebundenen Patienten die die angemessenen Möglichkeiten nicht gegeben worden sind, um optimale Geschicklichkeit im Gehen zu erreichen.

\section{REFERENCES}

Bramness, G. \& Natvig, H. (1975). Heterotopic ossification in spinal cord lesions T. Norske Lageforening, 27, 1522-1525.

Cheshire, D. J. E. (I968). The complete and centralised treatment of paraplegia. Paraplegia, 6, 59-73.

FoRNER, J. V. et al. (1976). Social and working conditions of our paraplegics. Paraplegia, 14, 74-79.

GJONE, R. \& NoRDLIE, L. (I978). Incidence of traumatic paraplegia and tetraplegia in Norway: A statistical survey of the years 1974 and 1975. Paraplegia, 16, 88-93.

GuttmanN, L. (1973). Spinal Cord Injuries. Comprehensive Management and Research, p. 633. Blackwell Scientific Publications, Oxford.

Johnson, G. S. et al. (1972). Problems of social integration for paraplegics in Scotland. Paraplegia, 10, 1 26-1 33 .

KAASA, L. \& MCADAM, R. (I967). A survey on the rehabilitation of paraplegics. The State Rehabilitation Institute in Oslo, Norway.

Maury, M. (1964). The future of paraplegics. Paraplegia, 2, I56.

McADAM, R. (I974). Physical training of paraplegics. Norsk Mensendieck-Forbunds Medlemsblad, 2, 2-23.

MeiniCKe, F. W. (I964). Social aspects of paraplegic coal-miners in Germany. Paraplegia, 2, 163-169.

Natvig, H. \& MCADAM, R. (1978). Ambulation without wheelchairs for paraplegics with complete lesions. Paraplegia, 16, I42-I46.

Nichols, P. J. R. et al. (1979). Wheelchair users shoulder? Shoulder pain in patients with spinal cord lesions. Scand. F. Rehab Med., II, 29-32.

Wilcox, N. E. (I972). Follow up of 423 consecutive patients admitted to the Spinal Cord Centre, Rancho Los Amigos Hospital, I January to 31 December 1967. Paraplegia, I0, I I 5-I 22 . 